\title{
Distribution extension of the Spectacled Petrel (Procellaria conspicillata) off the Argentine continental shelf and oceanic adjacent waters
}

\author{
Maximiliano Manuel Hernandez ${ }^{1}$, Sofía Copello ${ }^{1}$, Alexander Borowicz ${ }^{2} \&$ Juan Pablo Seco-Pon $^{1,3}$ \\ ${ }^{1}$ Grupo Vertebrados, Instituto de Investigaciones Marinas y Costeras (IIMyC), Consejo Nacional de Investigaciones Científicas y Técnicas \\ (CONICET), Universidad Nacional de Mar del Plata (UNMdP), Mar del Plata, Argentina. \\ Department of Ecology \& Evolution, Stony Brook University, Stony Brook, NY, U.S.A. \\ Corresponding author: secopon@mdp.edu.ar
}

Received on 14 December 2018. Accepted on 17 April 2019.

\begin{abstract}
The Spectacled Petrel Procellaria conspicillata is endemic of the Tristan da Cunha Archipelago, in the South Atlantic Ocean. However, it is scarcely detected in waters off Argentina beyond its traditional distribution along the southwest Atlantic during the breeding season. This study compiles distributional records of Spectacled Petrel for the target area (chiefly between $38^{\circ} \mathrm{S}$ to $46^{\circ} \mathrm{S}$ and $23^{\circ} \mathrm{W}$ to $57^{\circ} \mathrm{W}$ ) obtained in situ, from non-systematic observations at sea, between 2015 and 2018 (totaling 4 trips); and by literature review. Nineteen new sightings of the species are presented. In 46 sightings a total of 65 individuals were recorded chiefly within waters of the Argentine continental shelf $(<200 \mathrm{~m})(46 \%)$ and oceanic adjacent waters $(54 \%)$. The bulk of the sightings (95\%) were obtained during the species breeding season. In addition, we report the southernmost record of the species in oceanic waters for the southwest Atlantic $\left(46^{\circ} 10^{\prime} \mathrm{S} ; 57^{\circ} 06^{\prime} \mathrm{W}\right)$.
\end{abstract}

KEY-WORDS: breeding season, endemic, Procellaria petrels, range extension, southwest Atlantic.

The Spectacled Petrel (Procellaria conspicillata) disperses in the South Atlantic Ocean, from the north of Brazil to Argentina and off the western coast of southern Africa (Enticott \& O'Connell 1985). It is considered a vagrant to the Indian Ocean, where it has been reported in the vicinity of Amsterdam Island and Australia (Onley \& Scofield 2007, Shirihai 2008). The species is endemic of Inaccessible Island in the Tristan da Cunha Archipelago (Enticott \& O'Connell 1985, Ryan 1998, Ryan \& Moloney 2000). Its breeding season begins in September, with egg-laying in late October, hatching in midDecember, and fledging of chicks in early March (Ryan \& Moloney 2000, Ryan et al. 2006).

The total breeding population of Spectacled Petrel was estimated to be approximately 10,000 pairs in the 2004/2005 breeding season (Ryan et al. 2006). However, recent studies updated its population estimate to 14,400 breeding pairs (Ryan $\&$ Ronconi 2011). During $19^{\mathrm{th}}$ and early $20^{\text {th }}$ Centuries the species was threatened by the egg predation by wild pigs (Ryan 1998, Ryan et al. 2006), which has led to a significant reduction in the population (Ryan et al. 2006), with a lowest estimate of a few tens of pairs in 1937 (Hagen 1952). However, breeding birds are still affected, to a lesser extent, by heavy rains on their nesting colonies (Ryan et al. 2006). Currently, the
Spectacled Petrels are threatened mainly by the increased mortality associated with longline fishing vessels, chiefly in waters where they overlap with Brazilian fisheries fleet (Olmos 1997, 2001, Bugoni et al. 2009, Branco et al. 2014). The species is listed as "Vulnerable" by the International Union for the Conservation of Nature (IUCN) (BirdLife International 2018) due to its small breeding range and its susceptibility to stochastic events and human activities (ACAP 2018).

During the breeding season, the species feeds mainly in areas adjacent to Inaccessible Island, notably on the Walvis Chain, and moving further south on the continental shelf of South Africa up to $41^{\circ} \mathrm{S}$ near the Agulhas Bank (Enticott \& O'Connell 1985, Camphuysen 2001). However, recent studies conducted with satellite transmitters showed the Patagonian shelf off Argentina as a feeding site by at least some tracked individuals (Reid $e t$ al. 2014). Previous platform-of-opportunity based studies of the at-sea distribution of the Spectacled Petrel revealed that breeding individuals regularly attend waters of the southwestern sector of the Atlantic Ocean, including the Argentine continental shelf ( $<200 \mathrm{~m}$ depth) and adjacent oceanic areas (Imberti 2002, Savigny 2002, White et al. 2002, Black et al. 2005, Morrison \& Henry 2006, Ginsburg \& DeWitt 2013, Chavez et al. 2014, Seco-Pon 
\& Stein-III 2015, Quiñones \& Imberti 2018).

This study updates the information on the Spectacled Petrel distribution in the Argentine continental shelf region and adjacent oceanic waters during the species' breeding season.

Sightings were accomplished opportunistically aboard different vessels performing distinct activities and routes within the Argentine continental shelf region and adjacent oceanic waters (see Table 1 for details). The range of activities and routes of these vessels include (1) tourism in southern Patagonia, the Antarctic Peninsula and the Malvinas/Falkland Islands (three trips), and (2) commercial seismic surveys in adjacent oceanic waters within the Argentine Basin (one trip). The sightings were made during the austral summer (January-February), from 2015 to 2018. For each sighting, the sea state (measured on the Beaufort scale) and wind intensity (in knots) were registered.

Table 1. Summary of extant and recent sighting records of the Spectacled Petrel (Procellaria conspicillata) in waters of the southwest Atlantic off Argentina and oceanic adjacent waters, 2002-2018. F = flying, E = eating, $S=$ sitting on the water, n.r. $=$ not reported.

\begin{tabular}{|c|c|c|c|c|}
\hline Date (dd/mm/yyyy) & Location & No. of birds & Behavior & Source \\
\hline $09 / 02 / 2000$ & $48^{\circ} 47^{\prime} \mathrm{S} ; 62^{\circ} 21^{\prime} \mathrm{W}$ & 3 & $S$ & Savigny 2002 \\
\hline $03 / 2000$ & $50^{\circ} 20^{\prime} \mathrm{S} ; 57^{\circ} 41^{\prime} \mathrm{W}$ & 1 & n.r. & White et al. 2002 \\
\hline $12 / 1996$ & $54^{\circ} 23^{\prime} \mathrm{S} ; 55^{\circ} 45^{\prime} \mathrm{W}$ & 1 & n.r. & White et al. 2002 \\
\hline $13 / 03 / 2000$ & $46^{\circ} 14^{\prime} \mathrm{S} ; 59^{\circ} 11^{\prime} \mathrm{W}$ & 1 & n.r. & Imberti 2002 \\
\hline $13 / 03 / 2000$ & $45^{\circ} 28^{\prime} \mathrm{S} ; 58^{\circ} 54^{\prime} \mathrm{W}$ & 1 & n.r. & Imberti 2002 \\
\hline $14 / 03 / 2000$ & $41^{\circ} 44^{\prime} \mathrm{S} ; 57^{\circ} 36^{\prime} \mathrm{W}$ & 2 & n.r. & Imberti 2002 \\
\hline $14 / 02 / 2004$ & n.r. & 1 & n.r. & Black et al. 2005 \\
\hline $29 / 03 / 2006$ & n.r. & 1 & n.r. & Morrison \& Henry 2006 \\
\hline 03/02/2013 & $38^{\circ} 11^{\prime} \mathrm{S} ; 54^{\circ} 55^{\prime} \mathrm{W}$ & 1 & $\mathrm{~F}$ & Ginsburg \& DeWitt 2013 \\
\hline $13 / 02 / 2014$ & $38^{\circ} 55^{\prime} \mathrm{S} ; 56^{\circ} 00^{\prime} \mathrm{W}$ & 3 & $\mathrm{~F}$ & Seco-Pon \& Stein-III 2015 \\
\hline $18 / 01 / 2016$ & $38^{\circ} 25^{\prime} \mathrm{S} ; 54^{\circ} 48^{\prime} \mathrm{W}$ & 9 & $S, E$ & Quiñones \& Imberti 2018 \\
\hline $24 / 02 / 2008$ & $38^{\circ} 47^{\prime} \mathrm{S} ; 55^{\circ} 44^{\prime} \mathrm{W}$ & 1 & $\mathrm{~F}$ & Chavez et al. 2014 \\
\hline $27 / 02 / 2008$ & $38^{\circ} 46^{\prime} \mathrm{S} ; 55^{\circ} 44^{\prime} \mathrm{W}$ & 1 & $\mathrm{~F}$ & Chavez et al. 2014 \\
\hline $04 / 03 / 2008$ & $38^{\circ} 39^{\prime} \mathrm{S} ; 55^{\circ} 41^{\prime} \mathrm{W}$ & 2 & $\mathrm{~F}$ & Chavez et al. 2014 \\
\hline 09/03/2008 & $39^{\circ} 03^{\prime} \mathrm{S} ; 55^{\circ} 52^{\prime} \mathrm{W}$ & 1 & $\mathrm{~F}$ & Chavez et al. 2014 \\
\hline $13 / 03 / 2008$ & $39^{\circ} 02^{\prime} \mathrm{S} ; 55^{\circ} 53^{\prime} \mathrm{W}$ & 1 & $\mathrm{~F}$ & Chavez et al. 2014 \\
\hline $15 / 03 / 2008$ & $39^{\circ} 00^{\prime} \mathrm{S}, 55^{\circ} 53^{\prime} \mathrm{W}$ & 1 & $\mathrm{~F}$ & Chavez et al. 2014 \\
\hline $19 / 03 / 2008$ & $39^{\circ} 04^{\prime} \mathrm{S} ; 55^{\circ} 51^{\prime} \mathrm{W}$ & 1 & $\mathrm{~F}$ & Chavez et al. 2014 \\
\hline $10 / 04 / 2010$ & $36^{\circ} 26^{\prime} \mathrm{S} ; 54^{\circ} 09^{\prime} \mathrm{W}$ & 1 & $S$ & Chavez et al. 2014 \\
\hline $30 / 01 / 2012$ & $44^{\circ} 20^{\prime} \mathrm{S} ; 61^{\circ} 15^{\prime} \mathrm{W}$ & 1 & S,E & Chavez et al. 2014 \\
\hline $24 / 02 / 2013$ & $43^{\circ} 49^{\prime} \mathrm{S} ; 59^{\circ} 46^{\prime} \mathrm{W}$ & 1 & $\mathrm{~F}$ & Chavez et al. 2014 \\
\hline $25 / 02 / 2013$ & $43^{\circ} 39^{\prime} \mathrm{S} ; 59^{\circ} 41^{\prime} \mathrm{W}$ & 1 & $\mathrm{~F}$ & Chavez et al. 2014 \\
\hline $26 / 02 / 2013$ & $43^{\circ} 34^{\prime} \mathrm{S} ; 59^{\circ} 33^{\prime} \mathrm{W}$ & 1 & $\mathrm{~F}$ & Chavez et al. 2014 \\
\hline $27 / 02 / 2013$ & $43^{\circ} 27^{\prime} \mathrm{S} ; 59^{\circ} 40^{\prime} \mathrm{W}$ & 1 & $\mathrm{~F}$ & Chavez et al. 2014 \\
\hline $01 / 03 / 2013$ & $42^{\circ} 01^{\prime} \mathrm{S} ; 58^{\circ} 33^{\prime} \mathrm{W}$ & 1 & F & Chavez et al. 2014 \\
\hline $19 / 11 / 2013$ & $34^{\circ} 32^{\prime} \mathrm{S} ; 52^{\circ} 25^{\prime} \mathrm{W}$ & 2 & $\mathrm{~F}$ & Chavez et al. 2014 \\
\hline $28 / 05 / 2014$ & $42^{\circ} 06^{\prime} S ; 58^{\circ} 15^{\prime} \mathrm{W}$ & 1 & $S$ & Chavez et al. 2014 \\
\hline $15 / 01 / 2015$ & $39^{\circ} 13^{\prime} \mathrm{S} ; 56^{\circ} 08^{\prime} \mathrm{W}$ & 1 & $\mathrm{~F}$ & Present study \\
\hline $11 / 01 / 2016$ & $39^{\circ} 29^{\prime} \mathrm{S} ; 53^{\circ} 35^{\prime} \mathrm{W}$ & 1 & $\mathrm{~F}$ & Present study \\
\hline 09/01/2017 & $38^{\circ} 28^{\prime} \mathrm{S} ; 53^{\circ} 53^{\prime} \mathrm{W}$ & 2 & $\mathrm{~F}$ & Present study \\
\hline 08/01/2018 & $42^{\circ} 58^{\prime} \mathrm{S} ; 56^{\circ} 47^{\prime} \mathrm{W}$ & 1 & $\mathrm{~F}$ & Present study \\
\hline 08/01/2018 & $42^{\circ} 59^{\prime} \mathrm{S} ; 56^{\circ} 43^{\prime} \mathrm{W}$ & 1 & $\mathrm{~F}$ & Present study \\
\hline 09/01/2018 & $42^{\circ} 58^{\prime} \mathrm{S} ; 56^{\circ} 45^{\prime} \mathrm{W}$ & 1 & $\mathrm{~F}$ & Present study \\
\hline
\end{tabular}




\begin{tabular}{ccccl}
\hline Date (dd/mm/yyyy) & Location & No. of birds & Behavior & Source \\
\hline $09 / 01 / 2018$ & $42^{\circ} 57^{\prime} \mathrm{S} ; 56^{\circ} 46^{\prime} \mathrm{W}$ & 1 & $\mathrm{~S}$ & Present study \\
$09 / 01 / 2018$ & $43^{\circ} 20^{\prime} \mathrm{S} ; 56^{\circ} 34^{\prime} \mathrm{W}$ & 2 & $\mathrm{~S}$ & Present study \\
$11 / 01 / 2018$ & $43^{\circ} 05^{\prime} \mathrm{S} ; 56^{\circ} 04^{\prime} \mathrm{W}$ & 1 & $\mathrm{~F}$ & Present study \\
$11 / 01 / 2018$ & $43^{\circ} 05^{\prime} \mathrm{S} ; 56^{\circ} 17^{\prime} \mathrm{W}$ & 1 & $\mathrm{~F}$ & Present study \\
$18 / 01 / 2018$ & $44^{\circ} 22^{\prime} \mathrm{S} ; 57^{\circ} 05^{\prime} \mathrm{W}$ & 1 & $\mathrm{~F}$ & Present study \\
$19 / 01 / 2018$ & $46^{\circ} 10^{\prime} \mathrm{S} ; 57^{\circ} 06^{\prime} \mathrm{W}$ & 2 & $\mathrm{~F}$ & Present study \\
$24 / 01 / 2018$ & $43^{\circ} 13^{\prime} \mathrm{S} ; 56^{\circ} 23^{\prime} \mathrm{W}$ & 1 & $\mathrm{~F}$ & Present study \\
$30 / 01 / 2018$ & $42^{\circ} 57^{\prime} \mathrm{S} ; 55^{\circ} 48^{\prime} \mathrm{W}$ & 1 & $\mathrm{~F}$ & Present study \\
$30 / 01 / 2018$ & $43^{\circ} 13^{\prime} \mathrm{S} ; 56^{\circ} 20^{\prime} \mathrm{W}$ & 1 & $\mathrm{~F}$ & Present study \\
$31 / 01 / 2018$ & $43^{\circ} 21^{\prime} \mathrm{S} ; 55^{\circ} 51^{\prime} \mathrm{W}$ & 1 & $\mathrm{~F}$ & Present study \\
$31 / 01 / 2018$ & $43^{\circ} 05^{\prime} \mathrm{S} ; 55^{\circ} 15^{\prime} \mathrm{W}$ & 2 & $\mathrm{~F}$ & Present study \\
$01 / 02 / 2018$ & $43^{\circ} 18^{\prime} \mathrm{S} ; 55^{\circ} 50^{\prime} \mathrm{W}$ & 1 & $\mathrm{~F}$ & Present study \\
$01 / 02 / 2018$ & $43^{\circ} 11^{\prime} \mathrm{S} ; 56^{\circ} 29^{\prime} \mathrm{W}$ & 1 & $\mathrm{~F}$ & Present study \\
\hline
\end{tabular}

The bulk of the sightings included single individuals (79\%), flying at a minimum distance of $200 \mathrm{~m}$ from the stern of the ship (Figs. $1 \& 2)$. Few sightings $(n=$ 2) consisted of individuals recorded either floating and/ or actively feeding. Nineteen sightings encompassing up to 23 individuals were made from the vessels (Table 1 ), mainly between $38^{\circ} \mathrm{S}$ to $46^{\circ} \mathrm{S}$ and $23^{\circ} \mathrm{W}$ to $57^{\circ} \mathrm{W}$. Overall (pooled) sightings occurred on the shelf-break and the continental shelf, mainly at depths ranging from $84 \mathrm{~m}$ to $6280 \mathrm{~m}$ (Fig. 1). The closest position of a Spectacled Petrel sighting from the South American continent was about 95 nautical miles $(175 \mathrm{~km})$ SE off Mar del Plata, Argentina. At the time of the sightings, sea state (measured on the Beaufort scale) varied between 2 and 6, and wind speed between $11.7 \mathrm{kt}$ and $29 \mathrm{kt}$. On some occasions ( $-5 \%$ of total sightings) the species was observed in assemblages together with other seabirds, chiefly the White-chinned Petrel (P. aequinoctialis) and the Great Shearwater (Ardenna gravis) (tourism and seismic observations combined).

The compilation of previous records and the updated information presented here (Fig. $1 \&$ Table 1) clearly denote the use by the Spectacled Petrel, at least by some individuals, of the Argentine continental shelf and adjacent oceanic waters. They were recorded over 2000 $\mathrm{nm}(3700 \mathrm{~km})$ from its breeding area and more than 1080 $\mathrm{nm}(2000 \mathrm{~km})$ from the main area used by the species during the breeding season. Previous studies indicated that breeding adults concentrate their feeding activities along the mid-Atlantic ridge and along the continental shelf edge between $25-40^{\circ} \mathrm{S}$, with $50 \%$ of the feeding activities occurring around $500 \mathrm{~km}$ from their colony (Reid et al. 2014). Despite those findings, sightings of



Figure 1. Distribution of sightings of Spectacled Petrels (Procellaria conspicillata) in the Argentine continental shelf and adjacent oceanic waters for the period 2002-2018, based in literature review and records from this study. Continuous lines represent the $200 \mathrm{~m}$ and $1000 \mathrm{~m}$ depth isobaths. 


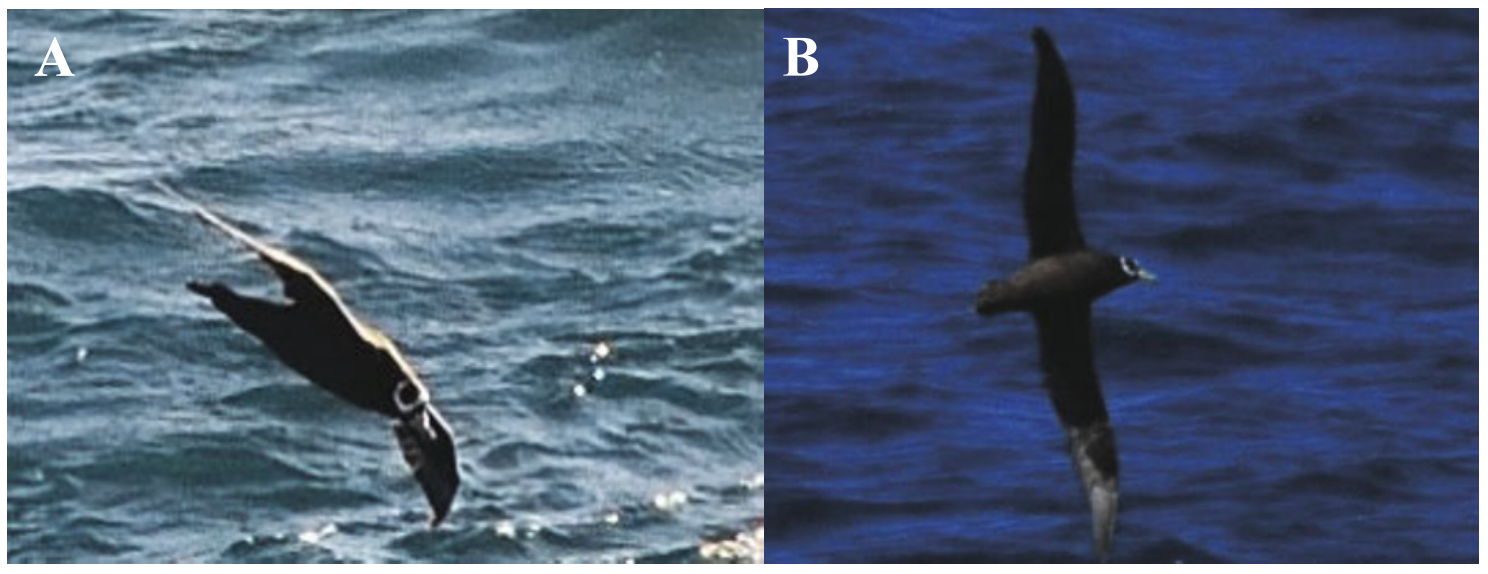

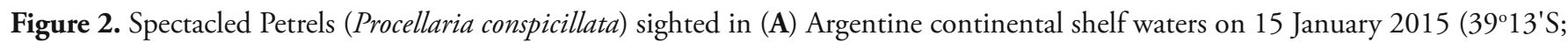
$\left.56^{\circ} 08^{\prime} \mathrm{W}\right)$; and $(\mathbf{B})$ in adjacent oceanic waters off Argentine shelf on 31 January $2018\left(43^{\circ} 05^{\prime}\right.$ S; 55 $15^{\prime}$ W). Photo author: J.P. Seco Pon (A), M. Hernandez (B).

the species in the Patagonian shelf waters off Argentina were expected as Reid et al. (2014) also revealed the use of this area as a feeding site by at least some individuals. Outside the breeding season, the species is found in deeper waters (> $3000 \mathrm{~m}$ depth) and shelf edges (1000$3000 \mathrm{~m}$ depth) (Bugoni et al. 2009). The main wintering area of this species occurs along the Brazilian continental shelf between São Paulo and Rio Grande do Sul states, in south-southeastern Brazil (Bugoni et al. 2009).

The presence of birds recorded in Argentine waters and adjacent oceanic waters could be due to the propensity of some individuals to attend commercial fishing activities, as is the case of the Spectacled Petrels recorded by Chavez et al. (2014) and Seco-Pon et al. (2017). Still, no bycatch of the species has been recorded so far in fisheries operating within the Argentine Economic Exclusive Zone (Seco-Pon et al. 2015). Other confirmed records of Spectacled Petrels interacting with fisheries in the region were obtained in Uruguay ( Jiménez \& Domingo 2007, Jiménez et al. 2011) and southern Brazil (Olmos 1997, Bugoni et al. 2009, Branco et al. 2014). There, the species is bycaught in longline fisheries at a rate estimated at 0.005 birds $/ 1000$ hooks and 0.008 birds $/ 1000$ hooks in pelagic longline fishing vessels operating off Uruguay and Brazil, respectively (Jiménez \& Domingo 2007, Bugoni et al. 2008).

The paucity of Spectacled Petrel records from Argentine waters may be due to a combination of the relatively low numbers of individuals present in the waters off Argentina during the breeding season as revealed by the literature review presented here or to the lack of personnel trained to identify them. Given that fisheries remain the main threat posed to this species (ACAP 2018), it is of great importance to increase the sampling effort to better understand the distribution and abundance of this species in the Patagonian shelf region and its interaction with human activities.

\section{ACKNOWLEDGEMENTS}

We thank Spectrumgeo Inc. and the crew of the HYSY760 during the navigations within waters of the Argentine Basin, and also the staff and crew of the Seabourn Quest during its routing in the southern cone of South America. One anonymous referee greatly improved a version of the manuscript with its suggestions and recommendations. This study was partially funded by the Universidad Nacional de Mar del Plata, the Agencia Nacional de Promoción Cientifica y Técnica (PICT2015-0262 JPSP) and CONICET.

\section{REFERENCES}

ACAP [Agreement on the Conservation of Albatrosses and Petrels]. 2018. Spectacled Petrel Procellaria conspicillata. http://www.acap. aq (Access on 07 April 2019).

BirdLife International. 2018. The IUCN red list of threatened Species 2018: Procelaria conspicillata. www.iucnredlist.org/ species/22728437/132659002 (Access on 26 November 2018).

Black A., Morrison M. \& Woods R. 2005. Rare and vagrant birds in the Falkland Islands 2004. Wildlife Conservation in the Falkland Conservation 5: 12-14.

Branco J.O., Fracasso H.A.A., Pérez J.A.A. \& Rodrigues-Filho J.L. 2014. An assessment of oceanic seabird abundance and distribution off the southern Brazilian coast using observations obtained during deep-water fishing operations. Brazilian Journal of Biology 74: 3-15.

Bugoni L., D'Alba L. \& Furness R.W. 2009. Marine habitat use of wintering Spectacled Petrels Procellaria conspicillata, and overlap with longline fishery. Marine Ecology Progress Series 374: 273-285.

Bugoni L., Mancini P.L., Monteiro D.S, Nascimento L. \& Neves T.S. 2008. Seabird bycatch in the Brazilian pelagic longline fishery and a review of capture rates in the southwestern Atlantic Ocean. Endangered Species Research 5: 137-147.

Camphuysen C.J. 2001. The distribution of Spectacled Petrels Procellaria conspicillata in the south-eastern Atlantic. Atlantic Seabirds 3: 113-124.

Chavez L.N., Tamini L.L., Coppa J.J. \& Aguilar E.E. 2014. Asociación del Petrel de Anteojos (Procellaria conspicillata) con 
buques pesqueros en el Mar Argentino. Hornero 29: 73-79.

Enticott J. \& O'Connell M. 1985. The distribution of the spectacled form of the White-chinned Petrel (Procellaria aequinoctialis conspicillata) in the South Atlantic Ocean. British Antarctic Survey Bulletin 66: 83-86.

Ginsburg P.A. \& DeWitt B. 2013. Primera documentación del Petrel de Anteojos (Procellaria conspicillata) para Argentina. Nuestras Aves 58: 55-56.

Hagen Y. 1952. Birds of Tristan da Cunha. Results of the Norwegian Scientific Expedition to Tristan da Cunha 1937-1938 20: 1-248.

Imberti S. 2002. At-sea records of three rarely reported petrel species in the south-western Atlantic Ocean. Marine Ornithology 30: 32-33.

Jiménez S. \& Domingo A. 2007. Albatros y petreles: su interacción con la flota de palangre pelágico uruguaya en el Atlántico Sudoccidental (1998-2006). ICCAT Collective Volume of Scientific Papers 60: 2110-2117.

Jiménez S., Domingo A., Abreu M. \& Brazeiro A. 2011. Structure of the seabird assemblage associated with pelagic longline vessels in the southwestern Atlantic: implications for bycatch. Endangered Species Research 15: 241-254.

Morrison M. \& Henry A. 2006. Rare and vagrant birds in the Falkland Islands 2006. Wildlife Conservation in the Falkland Conservation 8: $11-14$.

Olmos F. 1997. Seabirds attending bottom long-line fishing off southeastern Brazil. Ibis 139: 685-691.

Olmos F. 2001. Revisão dos registros de Procellaria conspicillata no Brasil, com novas observaçóes sobre sua distribuição. Nattereria 2: $16-18$.

Onley D. \& Scofield P. 2007. Albatrosses, petrels and shearwaters of the world. Princeton: Princeton University Press.

Quiñones J. \& Imberti S. 2018. Largest aggregation of Spectacled Petrel Procellaria conspicillata in Argentine waters. Cotinga 40: 74-78.

Reid T.A., Ronconi R.A., Cuthbert R.J. \& Ryan P.G. 2014. The summer foraging ranges of adult Spectacled Petrels Procellaria conspicillata. Antarctic Science 26: 23-32.
Ryan P.G. 1998. The taxonomic and conservation status of the Spectacled Petrel Procellaria conspicillata. Bird Conservation International 8: 223-235.

Ryan P.G., Dorse C. \& Hilton G.M. 2006. The conservation status of the Spectacled Petrel Procellaria conspicillata. Biological Conservation 131: 575-583.

Ryan P.G. \& Moloney C.L. 2000. The status of Spectacled Petrels Procellaria conspicillata and other seabirds at Inaccessible Island. Marine Ornithology 28: 93-100.

Ryan P.G. \& Ronconi R.A. 2011. Continued increase in numbers of Spectacled Petrels Procellaria conspicillata. Antarctic Science 23: 332-336.

Savigny C. 2002. Observaciones sobre aves marinas en aguas argentinas, sudeste Bonaerense y Patagonia. Cotinga 18: 81-84.

Seco-Pon J.P., Copello S., Tamini L., Mariano-Jelicich R., Paz J., Blanco G. \& Favero M. 2015. Seabird conservation in fisheries: current state of knowledge and conservation needs for Argentine high-seas fleets, p. 45-88. In: Mahala G. (ed.). Seabirds and songbirds: habitat preference, conservation and migratory behavior. New York: Nova Science Publishers.

Seco-Pon J.P., Jiménez S., Pin O., Tamini L., Chavez N., Loureiro A., Troncoso P., Coppa J.L., Aguilar E.E.E., Favero M., Copello S. \& Domingo A. 2017. El Petrel de Anteojos (Procellaria conspicillata) en aguas argentinas, Zona Común de Pesca Argentina-Uruguaya: observaciones desde las flotas pesqueras. Tigre: XVIII Simposio Científico Comisión Técnica Mixta del Frente Marítimo.

Seco-Pon J.P \& Stein-III W. 2015. A second documented record of Spectacled Petrel Procellaria conspicillata in Argentine waters. Revista Brasileira de Ornitologia 23: 29-30.

Shirihai H. 2008. The complete guide to Antarctic wildlife. Princeton: Princeton University Press.

White R.W., Gillon K.W., Black A.D. \& Reid J.B. 2002. The distribution of seabirds and marine mammals in Falkland Island waters. Peterborough: Joint Nature Conservation Committee.

Associate Editor: Leandro Bugoni. 